\title{
НАПРАВЛЕНИЕ ФОРМАЛИЗАЦИИ СВЕДЕНИЙ КРИМИНАЛИСТИЧЕСКОЙ ХАРАКТЕРИСТИКИ ДЛЯ РАССЛЕДОВАНИЯ ПРЕСТУПЛЕНИЙ
}

\section{THE DIRECTION OF FORMALIZATION OF INFORMATION FORENSIC CHARACTERISTICS FOR THE INVESTIGATION OF CRIMES}

P. Fesik

Summary. The article discusses the importance of the formalization of forensic knowledge and the importance of the formalization process for the further development of the institute of criminalistic characteristics of crimes. Various approaches of scientists to the concept of formalization are considered. The importance of formalization for a programmed description of a crime event based on the criminalistic characteristics of crimes is also considered. The conclusion is made about the need for formalization to integrate information technologies into the process of investigating crimes.

Keywords: formalization, crime investigation, forensic characteristics, three-level structure.
B криминалистической литературе многими учеными криминалистами уделяется существенное внимание такому направлению развития криминалистики как формализация криминалистических знаний.

Одни авторы пришли к выводу, что «формализация - это процесс отражения знаний об определенном объекте познания, основанный на формально-логическом подходе и заключается в предоставлении абстрактным положением конкретной формы путем использования формального языка» [9]. Другие ученые связывают формализацию с информационными системами, а именно рассматривают формализацию как «необходимое условие создания криминалистических информационно-поисковых систем» [1].

Значение процесса формализации для криминалистической науки в своих трудах подробно рассматривал Шаров В.И. Одним из важнейших особенностей формализации в криминалистике, он считал, что формализация необходима для использования в криминалистике математических методов и методов кибернетики [8].

\author{
Фесик Петр Юрьевич \\ К.ю.н., старший преподаватель, ФГБОУ ВО \\ «Волжский государственный университет водного \\ mранспорта» \\ fesik84@mail.ru
}

Аннотация. В статье рассматриваются вопросы значения формализации криминалистических знаний и значение процесса формализации для дальнейшего развития института криминалистической характеристики преступлений. Рассматриваются различные подходы ученых к понятию формализации. Также рассматривается значение формализации для программированного описания события преступления на основе криминалистической характеристики преступлений. Делается вывод о необходимости формализации для интегрирования информационных технологий в процесс расследования преступлений.

Ключевые слова: формализация, расследование преступлений, криминалистическая характеристика, трехуровневая структура.

На наш взгляд, можно согласиться с позицией авторов, которые указывают на формализацию как на условие дальнейшей интеграции информационных технологий с целью создания информационно-поисковых систем.

Кроме того, хотелось бы также выделить формализацию как необходимое условие создания «программированного описания» преступлений.

Под программированным описанием понимается возможность описания события с помощью перечня признаков или отдельных пунктов, последовательность которых называют программой сбора информации. Для этого необходимо создание программы (термин не подразумевает компьютерную программу) описания с указанием всех важных признаков данного события и их последовательности в регистрации.

Это имеет важное практическое значение, поскольку, программированное описание события лежит в основе создания компьютерных баз данных, что позволяет реализовать возможность накопления опыта следственных работников для возможности его ис- 
пользования следователями, которые еще не обладают достаточным опытом.

О необходимости упорядочивания процесса расследования и создания программированного описания преступления говорят Н.В.Кручинина и Н.С. Туренко. Они отмечают, что «создание компьютерных программ, называемых АРМ следователя - автоматизированное рабочее место следователя с целью повышения эффективности предварительного следствия, требует решения одной из весьма сложных задач: логического упорядочивания следственной деятельности и отображения её в виде последовательности действий и операций, часть из которых передается вычислительной машине» [6].

Необходимость в создании формализованного программированного описания преступления очевидна при анализе такого криминалистического понятия как криминалистическая характеристика преступлений.

При анализе криминалистической характеристики преступлений обнаружилось, что у ученых наблюдаются различные подходы к содержанию данного криминалистического института.

В частности, Л.А.Сергеев, про криминалистическую характеристику преступлений указывает следующее: «Особенности преступлений отдельных видов, имеющие значение для следственной практики и для разработки научных рекомендаций» [7]. Для его описания автор использовал шесть элементов: 1) способ совершения преступления; 2) условия совершения преступления; 3) обстановку; 4) объект преступного посягательства; 5) субъект преступления; 6) взаимосвязи между элементами.

В дальнейшем, различными авторами, в том числе В.Б. Веховым [2] А.В. Ковалевым [4], В.В. Трухачевым [5], А.В. Шмониным, Н.П. Яблоковым и д.р., изучались различные стороны криминалистической характеристики преступлений. Структура криминалистической характеристики преступлений анализировалась в основном с позиции включения различного количества элементов криминалистической характеристики преступления, а также их содержания и соотношения их с обстоятельствами, подлежащими доказыванию.

Имеющиеся различные представления о криминалистической характеристики преступлений существенно затрудняют возможность практического использования криминалистической характеристики преступлений при расследовании преступлений.

Нами рассматривалась трехуровневая структура криминалистической характеристики преступлений.
Наряду с элементами криминалистической характеристики преступлений и признаками, которые выражают свойства элементов, необходимо выделить уровень значений (градаций) признаков, который характеризовал бы ситуационное проявление уровня элементов.

Отличительной чертой уровня элементов от уровня признаков является тот факт, что последовательность описания системы от элементов к признакам представляет собой детализацию описания системы и движение от общего к частному. Элемент криминалистической характеристики преступлений может иметь множество свойств, поэтому сам элемент выступает в качестве общего для характеризующих его признаков, но установление свойств признака происходит через анализ конкретных значений признака. При описании преступления признаки образуют самостоятельный уровень криминалистической характеристики преступлений, этот уровень сам может быть детализирован. Детализация приводит к выделению нового (третьего) уровня криминалистической характеристики преступлений - уровня значений (градаций). Без указания значений признаков невозможно провести формализованное описание преступления. В связи с чем, анализ соотношений уровней признаков и значений имеет непосредственное практическое значение для практической реализации сведений, входящих в криминалистическую характеристику преступлений.

Под значениями (градациями) признаков мы понимаем конкретные значения последних. Например, мужской пол лица, совершившего преступление, является одной из двух градацией признака «пол», соответствующего элементу «субъект преступления».

Поскольку признак является носителем криминалистически значимой информации, то систему признаков можно использовать для создания субъективной модели преступления с помощью компьютерной программы. Предварительно необходимо определить все возможные значения каждого признака в этой системе.

Формализованное описание преступления на основе трехуровневой структуры криминалистической характеристики преступлений позволяет реализовать «криминалистическое описание вида или группы преступлений на основе трехуровневой структуры криминалистической характеристики преступлений», и в дальнейшем использовать подобное формализованное описание в качестве необходимого условия создания информационных систем для расследования преступления. Поэтому процедура ввода требует формализации.

Полное описание элементов, признаков и значений позволяет выделить типовые следственные ситуации первоначального этапа расследования. 
Типовая следственная ситуация начального этапа расследования убийства построена на типизированных криминалистически значимых данных, характеризующих места убийств, жертв убийств в этих местах и лиц, совершающих убийства этих же жертв в указанных местах [3]. Как видно из данного определения, следственная ситуация представляет собой те конкретные значения признаков, которые следователь встречает на месте преступления.
Дальнейшее развитие данного направления формализации криминалистических знаний позволит создать формализованное описание различных видов преступлений (преступлений против личности, преступлений против собственности, преступлений против общественного порядка и др.) Также развитие формализованного описания служит научной основой для практической реализации положений криминалистической характеристики преступлений.

\section{ЛИТЕРАТУРА}

1. Белкин Р.С. Курс криминалистики: В 3-х т. - Т. 2: Частные криминалистические теории / Р.С. Белкин.— М.: Юристь, 1997.— С. 48.

2. Вехов, В.Б. Компьютерные преступления: Способы совершения методики расследования [Текст] / В.Б. Вехов /- М.: Право и закон, 1996 - С. 28.

3. Видонов, Л.Г. Типовые следственные ситуации первоначального этапа следствия по делам об убийствах. Криминалистические взаимосвязи между элементами состава преступлений данного вида и методика выдвижения версий о лицах, совершивших убийства без очевидцев на основе указанных взаимосвязей [Текст] / Л.Г. Видонов.—Нижний Новгород - С. 13.

4. Ковалев, А.В. Криминалистическая характеристика преступлений в области охраны жизни и здоровья работников в процессе их производственной деятельности [Текст] / А.В. Ковалев // Актуальные направления развития криминалистической методики и тактики расследования.—- М., 1978.— C. 45.

5. Криминалистический анализ сокрытия преступной деятельности / Трухачев В.В.— Воронеж: Изд-во Воронеж. ун-та, 2000:.- 224 с.

6. Кручинина, Н.В.Логические основы выдвижения версий и компьютерные технологии [Текст] / Н.В. Кручинина, Н.С. Туренко // Вестник Ннгу им. Н.И. Лобачевского. Сер. Право, 2006. - Вып. 2 (10). - С. 253-256.

7. Сергеев, Л.А. Общие вопросы методики расследования преступлений [Текст] / Отв. ред.: Жогин Н.В.// Руководство для следователей.- М.: Юрид. литература, 1971.- С. 438.

8. Шаров В.И. Проблемы формализации криминалистического знания. / Вестник Нижегородского университета им. Н.И. Лобачевского. Серия ПраB0.2002. № 1. С. 264-273

9. Шевчук, В.М. Проблемы реализации тактических операций и формализация уголовного производства / В.М. Шевчук // Проблемы законности: сб. науч. тр. / Нац. ун-т «Юрид. акад. Украины им. Я. Мудрого».—Харьков, 2013.—Вып. 122.—C. 186-193 